${ }^{1}$ Instytut Archeologii

Uniwersytet Mikołaja Kopernika w Toruniu

${ }^{2}$ Instytut Nauk Geologicznych

Polska Akademia Nauk, Warszawa

\author{
Magdalena Sudot ${ }^{1}$, Kamil Adamczak ${ }^{1}$ \\ Maciej T. Krajcarz ${ }^{2}$, Magdalena Krajcarz ${ }^{2}$
}

\title{
ŚLAD OSADNICTWA Z WCZESNEJ EPOKI BRĄZU W SCHRONISKU W UDORZU II (UDÓRZ, GM. ŻARNOWIEC, WOJ. ŚLĄSKIE)
}

Zarys treści: Artykuł omawia wyniki interdyscyplinarnych badań sondażowych prowadzonych w 2012 roku na jaskiniowym stanowisku kultury mierzanowickiej w Udorzu, położonym na lewym brzegu doliny Udorki w południowo-wschodniej części Wyżyny Ryczowskiej (środkowa część Wyżyny Krakowsko-Częstochowskiej).

Słowa kluczowe: kultura mierzanowicka, osadnictwo holoceńskie, osady jaskiniowe, Wyżyna Krakowsko-Częstochowska

\section{Wstep}

Schronisko w Udorzu II zlokalizowane jest w północnej części doliny Udorki na Wyżynie Ryczowskiej (środkowa część Wyżyny Krakowsko -Częstochowskiej) w odległości około 15 m na zachód od zamku w Udorzu. Nie było ono dotychczas uwzględnione w pracach inwentaryzujących jaskinie, ani wzmiankowane w artykułach omawiających badania reliktów średniowiecznej rezydencji oraz pozostałości wałów, mimo że położone jest na tym samym wzniesieniu. Wyniki badań archeologicznych potwierdziły, że skraj wzgórza zamkowego był użytkowany w pradziejach jedynie przez ugrupowania społeczności kultury łużyckiej (Bartczak, Pietrzak 1988; 1992; Długoszewska, Pietrzak 2004-2005). 
Artykuł przedstawia wyniki interdyscyplinarnych badań sondażowych ${ }^{1}$ namuliska Schroniska w Udorzu II, przeprowadzonych latem 2012 roku, które stanowiły realizację jednego z etapów projektu polegającego na uchwyceniu śladów osadnictwa pradziejowego w dolinie Udorki i zbadaniu jego uwarunkowań paleośrodowiskowych ${ }^{2}$.

\section{Położenie i charakterystyka przyrodniczych walorów stanowiska}

Schronisko w Udorzu II położone jest na gruntach wsi Udórz, gm. Żarnowiec, woj. śląskie (N: 50²6'43" E: 1946'8”), na porośniętym lasem bukowym wzniesieniu zamkowym w formie cypla (około $20 \mathrm{~m}$ nad dnem doliny), znajdującym się u ujścia potoku Porębianka do okresowej rzeki Udorki, po wschodniej stronie doliny Udorki, na wysokości 345 m n.p.m. (ryc. 1). Dostęp do schroniska jest utrudniony przez bardzo strome stoki wzgórza tak od południa, jak zachodu i północy.

Obiekt ma charakter niszy skalnej, o powierzchni około $7 \mathrm{~m}^{2}$, pozbawionej własnego mikroklimatu. Otwór wejściowy skierowany jest na północny wschód (ryc. 2). Namulisko przed rozpoczęciem prac nie wykazywało śladów wcześniejszego rozkopywania, jak miało to miejsce w przypadku położonego w pobliżu Schroniska w Udorzu I.

Jaskinie, schroniska i nisze skalne położone w dolinie Udorki odznaczały się potencjalnie bardzo korzystnymi uwarunkowaniami środowiskowymi, sprzyjającymi zasiedlaniu ich w okresach pradziejowych. Płynące dolinami cieki i źródła krasowe przyciągały zwierzęta, które wędrując wąskimi dolinami stanowiły łatwy cel polowań, co potwierdzają źródła paleontologiczne w sąsiednich jaskiniach (Cyrek i in. 2010; Sudoł i in. 2013). Ponadto istotną przesłanką do podjęcia badań wykopaliskowych w opisywanym miejscu były

\footnotetext{
${ }^{1}$ Prace prowadzone były pod kierownictwem Magdaleny Sudoł (Instytut Archeologii Uniwersytetu Mikołaja Kopernika w Toruniu), przy współudziale geologa Macieja T. Krajcarza (Instytut Nauk Geologicznych PAN), archeozoologa Magdaleny Krajcarz (Instytut Nauk Geologicznych PAN) oraz studentów z Instytutu Archeologii Uniwersytetu Mikołaja Kopernika. Analizę materiału ceramicznego wykonał Kamil Adamczak z Instytutu Archeologii UMK. Prace terenowe oraz gabinetowe konsultowane były z prof. Krzysztofem Cyrkiem z Instytutu Archeologii UMK. Ze względu na położenie omawianego obszaru na terenie Lasów Państwowych i dodatkowo w rejonie występowania chronionych siedlisk i gatunków unikatowej flory, badania były konsultowane i nadzorowane przez Nadleśnictwo w Olkuszu i leśnictwo w Porębie Dzierżnej.

${ }^{2}$ Badania były finansowane ze środków grantu nr 2011/01/N/HS3/01299 pt. „Osadnictwo paleolityczne doliny Wodącej i doliny Udorki (Wyżyna Ryczowska) na tle uwarunkowań paleośrodowiskowych", finansowanego przez Narodowe Centrum Nauki.
} 
zlokalizowane w okolicy wychodnie jurajskich wapieni, zawierające dobrej jakości surowce krzemienne, pozyskiwane do produkcji narzędzi (Krajcarz M. T., Krajcarz M., Sudoł, Cyrek 2012a; 2012b).

\section{Materiaty i metody}

Przed badaniami wykopaliskowymi wykonano dwa odwierty geologiczne, dzięki którym udokumentowano występowanie osadów z holocenu i plejstocenu do głębokości $0,9 \mathrm{~m}$. Na tej podstawie wytypowano obszar w centralnej części niszy (ryc. 2), gdzie założono wykop sondażowy o powierzchni $1,5 \mathrm{~m}^{2}$. Sedymenty eksplorowano warstwami mechanicznymi o miąższości $10 \mathrm{~cm}$, w najgłębszym miejscu osiągając głębokość $110 \mathrm{~cm}$.

Ruchome źródła archeologiczne, tj. materiał ceramiczny oraz wyroby krzemienne poddano analizie typologicznej, technologicznej oraz porównawczej. Wykonano analizę granulometrii i morfologii gruzu wapiennego, zgodnie z metodyką przedstawioną przez Macieja T. Krajcarza i Teresę Madeyską (2010). Osady lessowe datowano metodami luminescencyjnymi TL i IRSL ${ }^{3}$.

Kości zwierząt zauważalne makroskopowo w sedymencie wydobywano bezpośrednio podczas eksploracji, a ich położenie dokumentowano trójwymiarowo. W każdym poziomie mechanicznym, uwzględniając warstwy naturalne, pobrano próbki osadu $\left(2 \times 5 \mathrm{~kg}\right.$ na $\left.1 \mathrm{~m}^{2}\right)$, które przepłukano na sitach $0,5 \mathrm{~mm}$ w celu pozyskania drobnych szczątków kostnych. Pozyskany w ten sposób materiał kostny oznaczono pod względem składu anatomicznego i pozycji w systematyce zoologicznej.

\section{Kontekst przyrodniczy}

Podczas badań stwierdzono obecność osadów gruzowych i piaszczysto -pyłowych o stosunkowo małej miąższości. Przejawiają one litologię typową dla facji przyotworowej osadów jaskiniowych Wyżyny Częstochowskiej (Krajcarz M. T., Sudoł, Krajcarz M., Cyrek 2012; Krajcarz i in. 2014). Namulisko zbudowane jest z czterech różnych litologicznie warstw (ryc. 3).

Najniżej położoną warstwę 4 tworzy regolit wapienny zalegający na spękanym podłożu skalnym, który przechodzi ku górze w rumosz wapienny. Okruchy gruzu są ostrokrawędziste, a powierzchnie spękań świeże, nieogładzone. Przestrzenie między okruchami wypełnia wapienny piasek zniewielką

\footnotetext{
${ }^{3}$ Datowania wykonał dr Jarosław Kusiak z Zakładu Geoekologii i Paleogeografii Uniwersytetu Marii Curie-Skłodowskiej w Lublinie.
} 

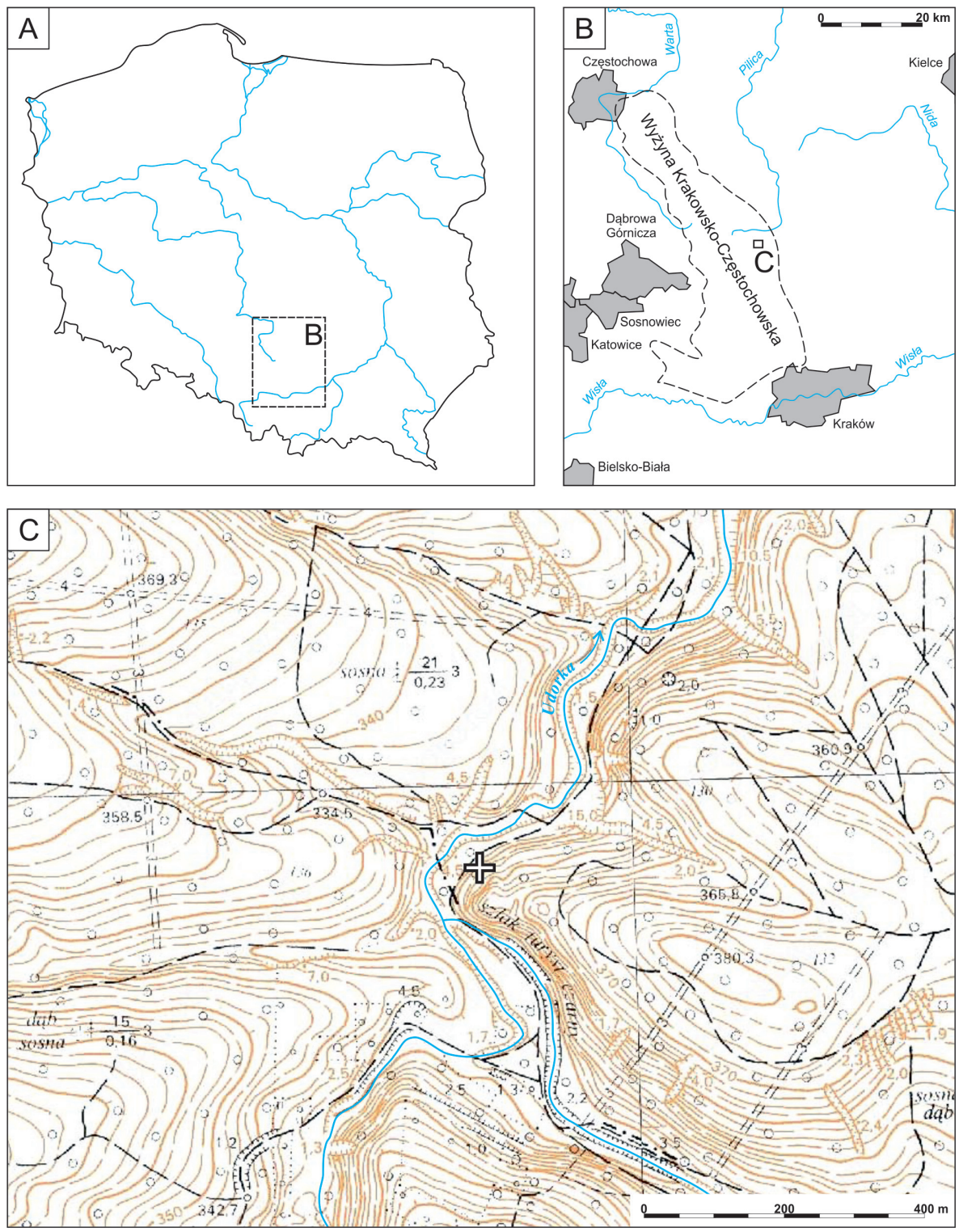

Ryc. 1. Udórz, gm. Żarnowiec. Lokalizacja Schroniska w Udorzu II: A - na tle mapy Polski, B - na tle Wyżyny Krakowsko-Częstochowskiej (granice makroregionu - wg Kondracki 1998), C - w Dolinie Udorki (http://geoportal. gov.pl/, z uzupełnieniem M. Sudoł i M. T. Krajcarza)

Fig. 1. Udórz, Żarnowiec Commune. Location of Rockshelter in Udórz II: A - on a map of Poland, B - on a map of the Kraków-Częstochowa Upland (macroregion boundaries - after Kondracki 1998), C - in the Udorka valley (http://geoportal.gov.pl/, amended by M. Sudoł and M. T. Krajcarz) 


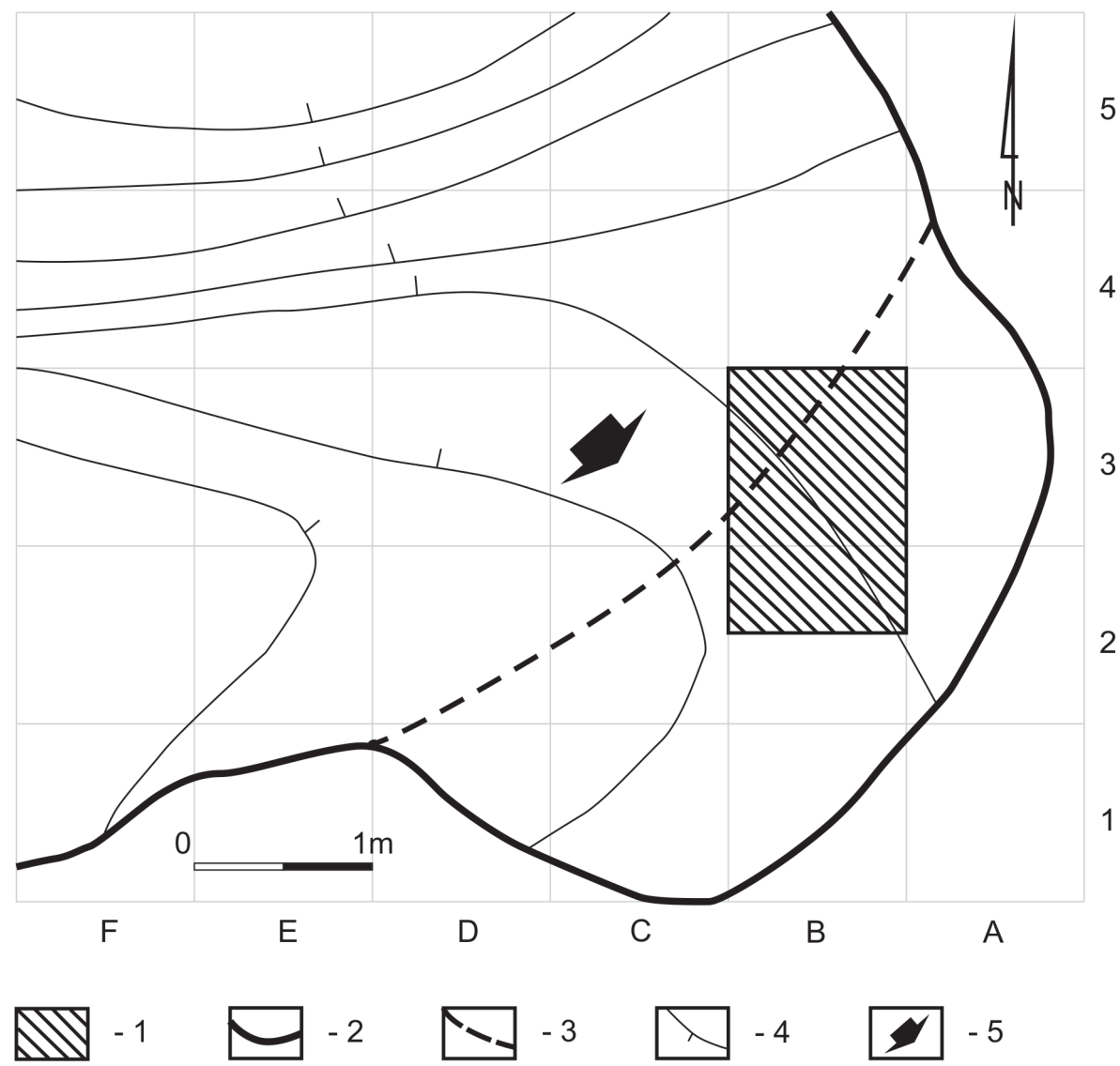

Ryc. 2. Udórz, gm. Żarnowiec, Schronisko w Udorzu II. Lokalizacja wykopu sondażowego. Objaśnienia: 1 - wykop sondażowy, 2 - zarys ścian skalnych, 3 - przebieg okapu, 4 - poziomice co $25 \mathrm{~cm}, 5$ - otwór wejściowy (rys. M. T. Krajcarz, M. Sudoł)

Fig. 2. Udórz, Żarnowiec Commune, Rockshelter in Udórz II. Location of trial trench. Legend: 1 - trial trench, 2 - extent of rock faces, 3 - line of overhang, 4 - contour lines at 25 -cm intervals, 5 - entrance (drawing: M. T. Krajcarz, M. Sudoł)

domieszką jasnoszarego (10YR 7/2) drobnego materiału. Osad powstał wskutek wietrzenia mrozowego w warunkach zimnego klimatu. Warstwa nie zawiera źródeł archeologicznych ani paleozoologicznych.

Warstwa 3 to jasnobrązowy (10YR 6/3) piasek pylasty z dużą zawartością ostrokrawędzistego gruzu w dolnej części. Ku stropowi udział gruzu stopniowo maleje i osad nabiera charakteru piaszczystego lessu. Warstwa powstała podczas maksimum ostatniego zlodowacenia, co potwierdzają datowania 


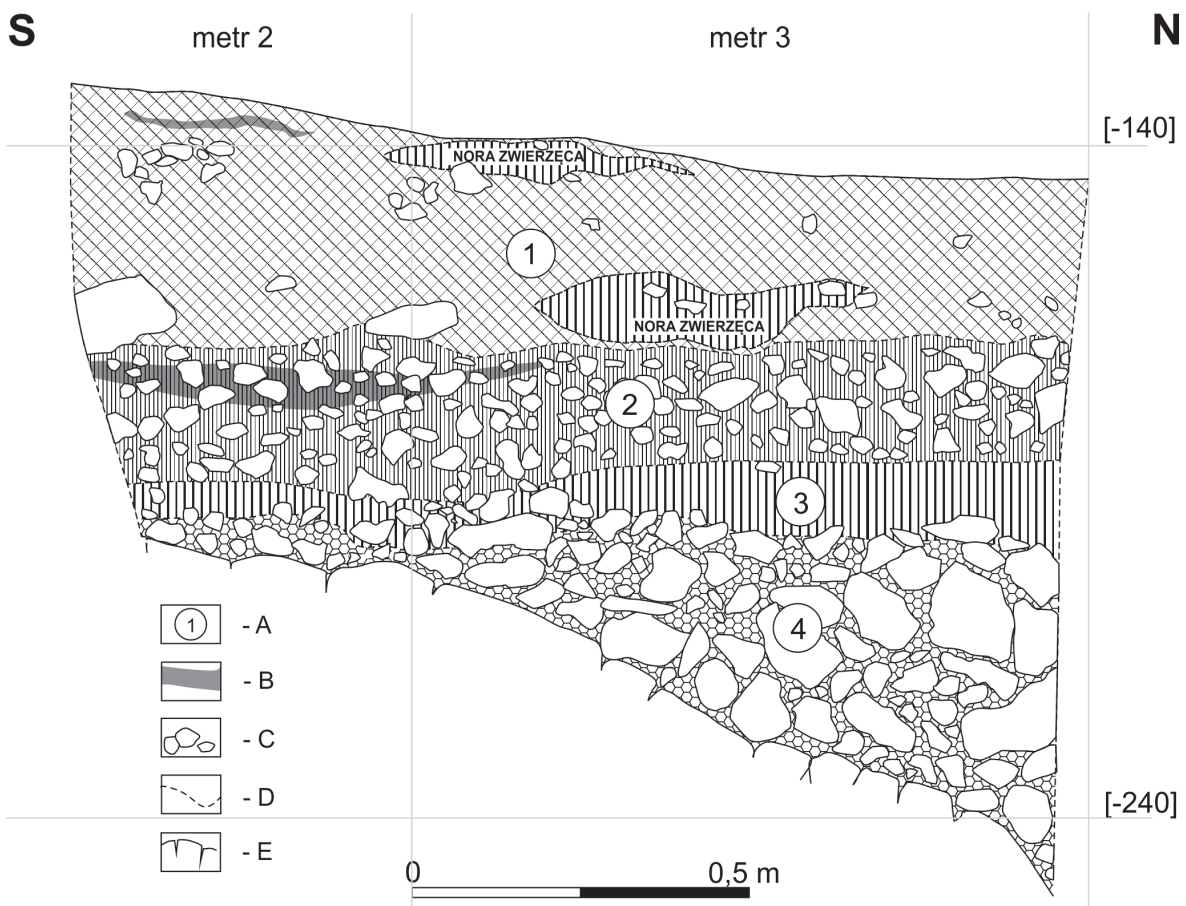

Ryc. 3. Udórz, gm. Żarnowiec, Schronisko w Udorzu II. Profil zachodni wykopu. Objaśnienia: A - numer warstwy, B - paleniska, C - gruz wapienny, D - granice warstw, E - skała (rys. M. T. Krajcarz, M. Sudoł)

Fig. 3. Udórz, Żarnowiec Commune, Rockshelter in Udórz II. West section of trial trench. Legend: A - layer number, B - hearths, $\mathrm{C}$ - limestone debris, D - layer boundaries, E - rock (drawing: M. T. Krajcarz, M. Sudoł)

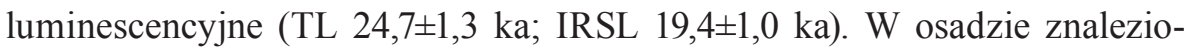
no nieliczne kości drobnych kręgowców oraz kuny i lisa (tab. 1). Obecność szczątków tego kopiącego nory drapieżnika wskazuje, że osad może być częściowo przemieszany, a część fauny stanowi domieszki pochodzące z późniejszego okresu. Obiekt wypełniony redeponowanym osadem warstwy 3 , będący reliktem nory zwierzęcej, znaleziono wyżej, na poziomie warstwy 1 .

Warstwę 2 stanowi szarobrązowy (10YR 5/2) piasek pylasty z dużą zawartością gruzu wapiennego. W dolnej części ma on charakter ostrokrawędzisty, przypominając niżej położone warstwy, ale ku górze zwiększa się udział gruzu ogładzonego, co wskazuje na akumulację osadu w warunkach stopniowo ocieplającego się klimatu. Warstwę należy wiązać ze schyłkiem plejstocenu i większą częścią holocenu. W osadzie występują między innymi szczątki kostne leśnych gryzoni, a w stropowej części również kreta i zająca (tab. 1). 
B

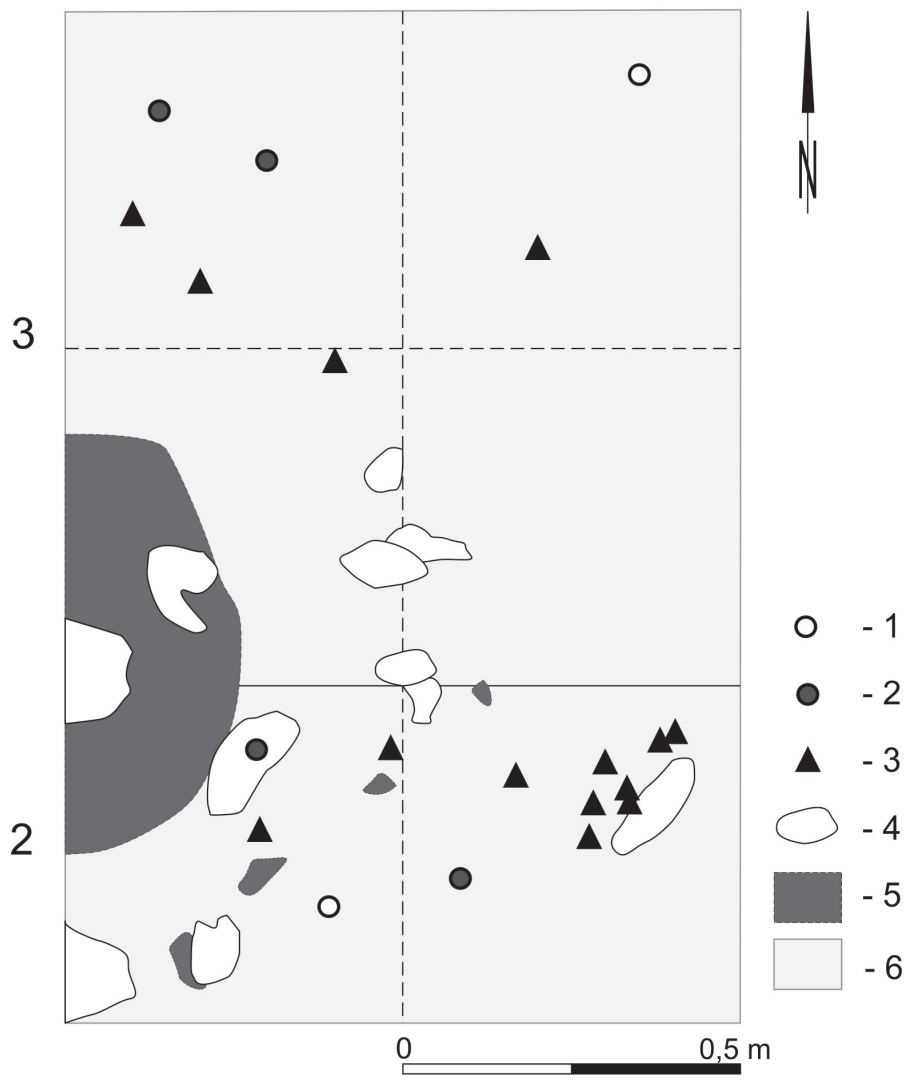

Ryc. 4. Udórz, gm. Żarnowiec, Schronisko w Udorzu II. Planigrafia poziomu kulturowego. Objaśnienia: 1 - wyroby krzemienne nieprzepalone, 2 - wyroby krzemienne przepalone, 3 - fragmenty naczyń ceramicznych, 4 - gruz wapienny, 5 - relikty paleniska, 6 - sedyment naturalny (rys. M. Sudoł)

Fig. 4. Udórz, Żarnowiec Commune, Rockshelter in Udórz II. Plan of occupation level. Legend: 1 - unburnt flintwork, 2 - burnt flintwork, 3 - pottery sherds, 4 - limestone debris, 5 - hearth remains, 6 - natural sediment (drawing: M. Sudoł)

Warstwa 1 zbudowana jest z ciemnego szarobrązowego (10YR 4/2) piasku pylastego z niewielkim udziałem ogładzonego gruzu wapiennego. Skład gatunkowy fauny kopalnej nawiązuje do stropowej części warstwy 2. Przeważają zwierzęta leśne, takie jak: kuna leśna, zając szarak, nornica ruda, kret europejski (tab. 1). Osad ten powstał w ciepłych warunkach klimatycznych późnego holocenu. 
Tabela 1. Udórz, gm. Żarnowiec, Schronisko w Udorzu II. Zestawienie oznaczonych szczątków fauny kopalnej (NISP/MNI)

\begin{tabular}{|l|c|c|c|c|c|}
\hline \multicolumn{1}{|c|}{ Takson } & \multicolumn{5}{c|}{ Warstwa } \\
& 1 & 2 strop & 2 środek & 2 spąg & 3 \\
\hline Sorex sp. ryjówka & & $1 / 1$ & $1 / 1$ & & \\
\hline Talpa europaea kret europejski & $1 / 1$ & $2 / 1$ & & & \\
\hline Erinaceus sp. jeż & & & & & $1 / 1$ \\
\hline Arvicola amphibious karczownik ziemnowodny & $1 / 1$ & $1 / 1$ & & & $1 / 1$ \\
\hline Microtus agrestis/arvalis nornik bury/polny & $2 / 1$ & $1 / 1$ & $1 / 1$ & & $3 / 2$ \\
\hline Microtus subterraneus darniówka zwyczajna & $2 / 1$ & $2 / 1$ & $2 / 1$ & & $1 / 1$ \\
\hline Clethrionomys glareolus nornica ruda & $3 / 1$ & $10 / 7$ & $3 / 2$ & & \\
\hline Cricetus cricetus chomik europejski & & & $1 / 1$ & & \\
\hline Apodemus agrarius mysz polna & & $1 / 1$ & & & \\
\hline Apodemus sp. mysz & & $8 / 6$ & & & $1 / 1$ \\
\hline Sicista sp. smużka & & & $1 / 1$ & & \\
\hline Eliomys quercinus żołędnica & & & & $1 / 1$ & \\
\hline Sciuridae indet. wiewiórkowate nieoznaczone & & & $1 / 1$ & & $1 / 1$ \\
\hline Lepus europaeus zając szarak & $1 / 1$ & & & & \\
\hline Lepus sp. zając & & $1 / 1$ & & & \\
\hline Vulpes vulpes lis pospolity & & & & & $1 / 1$ \\
\hline Martes martes kuna leśna & $1 / 1$ & & & & \\
\hline Martes sp. kuna & & & & & $1 / 1$ \\
\hline Carnivora indet. drapieżne nieoznaczone & & & & & $1 / 1$ \\
\hline Sus scrofa/Sus domesticus dzik/świnia domowa & & & $1 / 1$ & \\
\hline Artiodactyla indet. parzystokopytne nieoznaczone & $1 / 1$ & & & & \\
\hline
\end{tabular}

Zbiór kości zwierzęcych z opisywanego stanowiska jest bardzo nieliczny, w związku z tym trudno wnioskować o jego genezie. Szczątki drobnych ssaków są prawdopodobnie pozostałościami wypluwek ptaków drapieżnych (Andrews 1990). Na kościach dużych ssaków nie stwierdzono śladów obróbki. Natomiast w przypadku czterech egzemplarzy (ze stropowych części warstw 1 i 2 oraz z warstwy 3) odnotowano ślady, których wygląd pozwala sądzić, że powstały na skutek przejścia przez aparat trawienny ssaków mięsożernych. Niewykluczone zatem, że przynajmniej część depozytu jest efektem właśnie takich procesów.

\section{Planigrafia poziomu kulturowego}

Wyroby krzemienne, ułamki naczyń ceramicznych oraz relikt paleniska zarejestrowano na pograniczu warstw 1 i 2, a także w stropowej części warstwy 2, na głębokości od 20 do $40 \mathrm{~cm}$ od powierzchni terenu. Różnice w głębokości ich zalegania mają niewątpliwie związek z przemieszczaniem spowodowanym procesami wymarzania oraz z kopaniem nor przez zwierzęta. 
$\mathrm{Z}$ analizy planigraficznej wynika, że znaleziska tworzą skupisko wokół paleniska, którego ślady uchwycono w południowo-zachodniej części wykopu sondażowego (ryc. 4). Zadokumentowane w jego bezpośrednim sąsiedztwie duże bloki gruzu wapiennego tworzą regularny układ wokół koncentracji węgli drzewnych i mogły stanowić kamienną obstawę paleniska.

Podkreślić należy, że większość materiałów krzemiennych występuje w tym samym skupieniu co ułamki naczyń ceramicznych oraz wykazuje ślady przepalenia. Obserwacje te stanowią przesłankę do wnioskowania o homogeniczności poziomu kulturowego.

\section{Wyroby krzemienne}

Znaleziska te stanowią bardzo nieliczny zbiór, są to: jeden masywny wiór uszkodzony w części wierzchołkowej (ryc. 5: 1), trzy odłupki, w tym jeden fragment (ryc. 5: 2, 3), jedna łuska i jeden odpadek. Analiza powierzchni półsurowca i brak powierzchni korowych wskazują, że pochodzą one z zaawansowanego stadium produkcji surowca krzemiennego, przy której używano twardego tłuczka.

Ze względu na mocne przepalenie wyrobów krzemiennych, w większości przypadków nie można było określić surowca. Jedynie na podstawie fragmentu wióra oraz jednego odłupka stwierdzono jedną z lokalnych odmian krzemienia jurajskiego (Krajcarz M. T., Krajcarz M., Sudoł, Cyrek 2012a; 2012b).

Na podstawie nielicznego i mało charakterystycznego materiału krzemiennego trudno było precyzyjne określić przynależność chronologiczno -kulturową. Jedynie w przypadku fragmentu wióra krzemiennego na podstawie cech morfometrycznych wskazano epokę neolitu lub wczesne okresy epoki brązu, co odpowiada ustaleniom wynikającym z analizy materiału ceramicznego (por. niżej).

Bliskie analogie dla analizowanego materiału krzemiennego znajdujemy na sąsiednich stanowiskach, z których znane są późnoneolityczne i wczesnobrązowe pracownie związane z produkcją siekier krzemiennych, tj. w Jaskini Biśnik (Jaskinia Biśnik 2002; Pelisiak 1993-1994; Pelisiak, Muzolf 1992), Jaskini Jasnej Strzegowskiej (Mirosław-Grabowska, Cyrek 2009; Pelisiak 2003-2004; 2006) oraz Schronisku nad Jaskinią Zegar (Krajcarz M. T., Sudoł, Krajcarz M., Cyrek 2012). 


\section{Materiaty ceramiczne}

Ze stanowiska pozyskano 15 fragmentów naczyń ceramicznych, w tym 11 ułamków brzuśców, trzy wylewów i jedną łuskę (fragment z zachowaną jedną ścianką naczynia); na większości z nich stwierdzono ornament (8 szt.). Mimo niewielkiej liczebności zbioru, ma on cechy, które pozwalają określić przynależność kulturową pozostałości osadnictwa oraz ich ramową chronologię względną.

Masa ceramiczna została schudzona przede wszystkim domieszką mineralną o wielkości ziaren poniżej $6 \mathrm{~mm}$. W ośmiu przypadkach stwierdzono udział różowego thucznia, w pięciu przezroczysto-białego, a w jednym różnokolorowego. Jeden fragment pochodzi z naczynia przygotowanego w technologii bez udziału domieszek mineralnych. Przełamy są lekko gruzełkowate, rzadziej jednolite, powierzchnie zewnętrzne wygładzone. W zbiorze stwierdzono cztery ułamki naczyń zdobionych odciskami sznura, w tym dwa o prostym układzie pasm poziomych (ryc. 5: 6, 12). Ponadto na fragmencie wylewu odnotowano wątek pasma potrójnego (ryc. 5: 4), na fragmencie szyjki zaś motyw dwuelementowy - pod pasmem poziomym znajdują się krótkie odciski sznura w układzie pionowym (ryc. 5: 5). Cztery ułamki zdobione są jednoelementowymi wątkami odciskanymi stemplem. W trzech przypadkach ornament zlokalizowany jest powyżej największej wydętości brzuśca (ryc. 5: 7, 9, 10), w jednym zaś pod krawędzią wylewu (ryc. 5: 8). Ze względu na stan zachowania materiałów ceramicznych trudno jest określić formy naczyń. Można jedynie stwierdzić, że w zbiorze obecne są pozostałości co najmniej trzech pojemników, w tym prawdopodobnie jednej misy (ryc. 5: 4).

Opierając się na wynikach studiów nad garncarstwem wczesnobrązowym ze stanowiska Babia Góra w Iwanowicach (Kadrow 1991), można stwierdzić, że rodzaje domieszek schudzających masę ceramiczną, jakie stwierdzono w materiałach ze Schroniska w Udorzu II, obecne były przez cały okres trwania tradycji garncarskich wspólnot mierzanowickich (Kadrow 1991, s. 46-49). Walor datujący ma udział komponentów drobnych i średnich domieszek mineralnych oraz wygładzanie powierzchni zewnętrznych naczyń, które przeważają w początkowych etapach rozwoju omawianej kultury. $\mathrm{Na}$ taką chronologię zbioru wskazuje również obecność ornamentyki sznurowej",

${ }^{4} \mathrm{~W}$ późnych fazach kultury mierzanowickiej społeczności wczesnobrązowe powróciły do stosowania ornamentu sznurowego. Jedynie w grupie giebułtowskiej, z którą wiążą się materiały z obszaru Wyżyny Krakowsko-Częstochowskiej, tego typu zdobnictwo miało marginalne znaczenie (Kadrow, Machnik 1997, s. 113-114). 

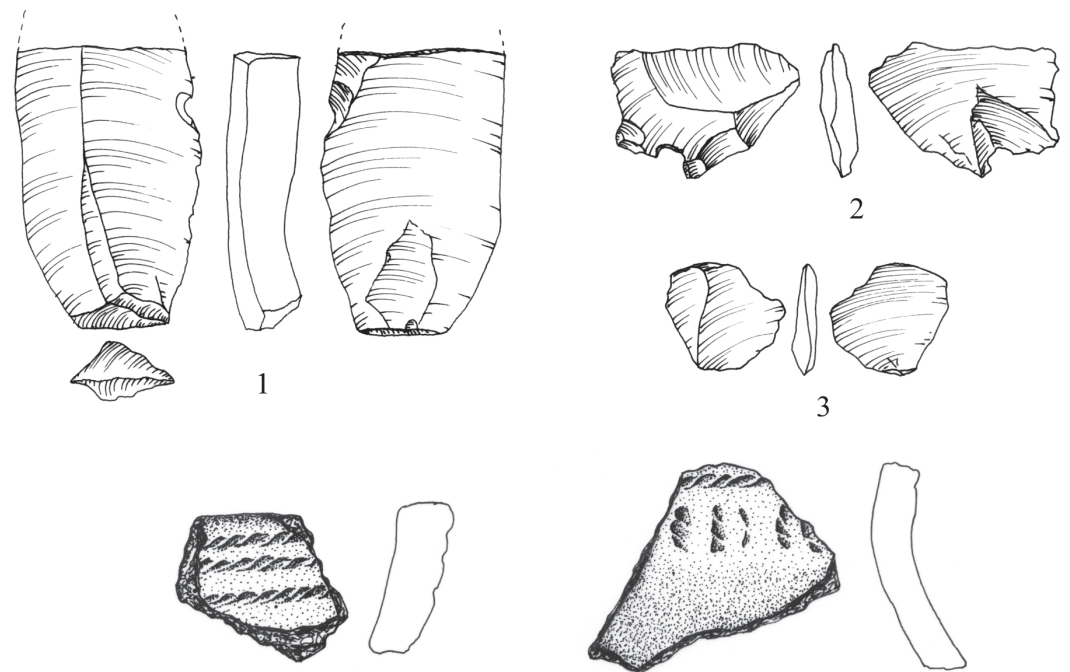

4

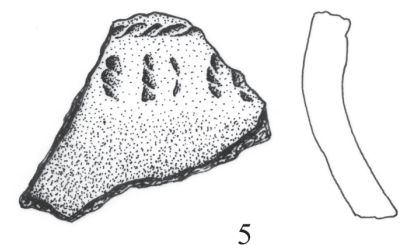

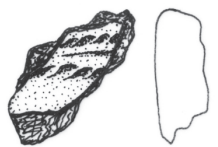

6

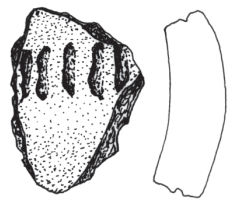

9
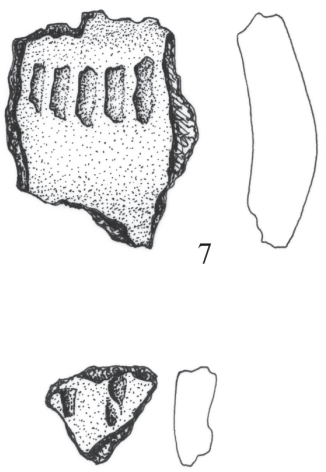

10

$5 \mathrm{~cm}$
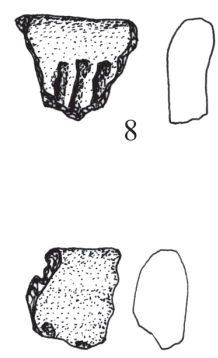

11

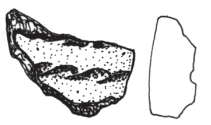

12

Ryc. 5. Udórz, gm. Żarnowiec, Schronisko w Udorzu II. Wybór materiałów źródłowych: 1-3 - wyroby krzemienne, 4-12 - zdobione fragmenty naczyń ceramicznych (rys. M. Sudoł)

Fig. 5. Udórz, Żarnowiec Commune, Rockshelter in Udórz II. Selection of finds: 1-3 - flintwork, 4-12 - decorated pottery sherds (drawing: M. Sudoł) 
którą przestano stosować w fazie klasycznej (Kadrow, Machnik 1997, s. 56). Dla materiałów z fazy wczesnomierzanowickiej typowy jest wątek potrójnych pasm odcisków sznura (np. Kadrow 1991, tabl. II: m, XXVII: a), oraz podkreślanie ostatniego, dolnego pasma przez krótkie odcinki wykonywane różnymi technikami ornamentacyjnymi (np. Machnik 1978, tabl. XVI: 2, 5; Kadrow, Machnik 1997, ryc. 13: C2, D1, 14: 5, 13, 34; 16: 19, 23). Natomiast proste wątki odciskane stemplem znane są z różnych etapów rozwoju garncarstwa wczesnej epoki brązu w Małopolsce (np. Machnik 1978, tabl. XI: 6; Kadrow 1991, tabl. IV: i, XXVIII: c; Kadrow, Machnik 1997, ryc. 9: 5).

Zebrane dane wraz z wynikami analizy planigraficznej, wskazującymi na jednoczasowość materiałów ceramicznych, pozwalają przyporządkować analizowany zbiór do wczesnego etapu rozwoju kultury mierzanowickiej, który datowany jest na okres 2200-2050 p.n.e. (Kadrow, Machnik 1997, s. 44).

\section{Wnioski}

Na stanowisku Schronisko w Udorzu II zadokumentowano typowe dla Wyżyny Częstochowskiej osady charakterystyczne dla przyotworowych części jaskiń, w których wystąpiły relikty fauny z holocenu i schyłku plejstocenu. W wykopie badawczym rozpoznano fragment obozowiska społeczności z wczesnej epoki brązu. Grupa ludności kultury mierzanowickiej zaadaptowała schronisko do krótkotrwałego pobytu w początku III tys. p.n.e. Pod osłoną nawisu skalnego usytuowano ognisko, przy którym obozowano i obrabiano krzemień.

W wyniku badań początków epoki brązu w Małopolsce stwierdzono, że wspólnoty schyłkowoneolityczne i wczesnobrązowe nie zamieszkiwały w sposób trwały Wyżyny Krakowsko-Częstochowskiej, a jedynie penetrowały jej obszar poszukując surowców krzemiennych oraz prawdopodobnie rzadkich roślin i owoców. Stabilne mikroregiony osadnicze wspólnot mierzanowickich znajdowały się na lessach małopolskich (Kadrow 2006, s. 464).

Fragmentarycznie odsłonięte relikty obozowiska na stanowisku Schronisko w Udorzu II potwierdzają dotychczasowe wnioski dotyczące modelu osadnictwa społeczności kultury mierzanowickiej na obszarach krasowych Wyżyny Krakowsko-Częstochowskiej. Obiekty o analogicznym charakterze znamy z Jaskini Biśnik, położonej w Dolinie Wodącej, około $7 \mathrm{~km}$ na południowy zachód (Jaskinia Biśnik 2002). Ponadto z okolicznych, wspomnianych powyżej stanowisk jaskiniowych znane są pracownie siekier krzemiennych, datowane na eneolit lub wczesną epokę brązu. Wyroby krzemienne 
i towarzyszący im materiał ceramiczny odkrywane są zawsze na tarasach przedjaskiniowych i w częściach przyotworowych. Znaleziska znane z południowej części Wyżyny Ryczowskiej wskazują, że społeczności ze schyłku neolitu i wczesnej epoki brązu unikały partii jaskiń, gdzie nie docierało światło dzienne. Sytuację taką stwierdzono w Jaskini Biśnik oraz w innych obiektach jaskiniowych tego mikroregionu, na przykład w Jaskini Jasnej Strzegowskiej (Mirosław-Grabowska, Cyrek 2009) oraz Schronisku nad Jaskinią Zegar (Krajcarz M. T., Sudoł, Krajcarz M., Cyrek 2012). Biorąc pod uwagę powyższe spostrzeżenia można przypuszczać, że w tym czasie obok większych jaskiń chętnie adaptowano do krótkotrwałego osadnictwa również mniejsze obiekty, takie jak Schronisko w Udorzu II.

\section{Literatura}

Andrews P.

1990 Owls, caves and fossils, London.

Bartczak A., Pietrzak J.

1988 Wyniki badań archeologiczno-architektonicznych zamku położonego koło Udorza, gm. Żarnowiec, woj. katowickie, maszynopis w archiwum Wojewódzkiego Urzędu Ochrony Zabytków w Katowicach, Łódź.

1992 Wyniki badań archeologiczno-architektonicznych w latach 1987-1988 i 1990 na terenie zespołu umocnień (zamek i tzw. podzamcze) położonego koło Udorza, gm. Żarnowiec, woj. katowickie, maszynopis w archiwum Wojewódzkiego Urzędu Ochrony Zabytków w Katowicach, Łódź.

Jaskinia Biśnik

2002 Jaskinia Biśnik. Rekonstrukcja zasiedlenia jaskini na tle zmian środowiska przyrodniczego, red. K. Cyrek, Torun.

Cyrek K., Socha P., Stefaniak K., Madeyska T., Mirosław-Grabowska M., Sudoł M., Czyżewski Ł.

2010 Palaeolithic of Biśnik Cave (Southern Poland) within the environmental background, Quaternary International, t. 220, s. 5-30 (DOI: 101016/j. quaint.2009.09.014).

Długoszewska W., Pietrzak J.

2004-2005 Wstęne wyniki badań terenowych przeprowadzonych w sierpniu 2003 roku na stanowisku 2 w Udorzu, gm. Żarnowiec, woj. śląskie (AZP 9455/2), Łódzkie Sprawozdania Archeologiczne, t. 9, s. 177-185.

Kadrow S.

1991 Iwanowice, stanowisko Babia Góra. Cześć I. Rozwój przestrzenny osady z wczesnego okresu epoki brązu, Kraków. 
2006 Późny neolit i wczesna epoka brąu na Jurze Ojcowskiej, [w:] Jura Ojcowska $w$ pradziejach $i$ w początkach państwa polskiego, red. J. Lech, J. Partyka, Ojców, s. 459-473.

Kadrow S., Machnik J.

1997 Kultura mierzanowicka. Chronologia, taksonomia i rozwój przestrzenny, Kraków.

Kondracki J.

1998 Geografia regionalna Polski, Warszawa.

Krajcarz M. T., Krajcarz M., Sudoł M., Cyrek K.

2012a From far or from near? Map of silicite raw material outcrops around the Biśnik Cave, [w:] Abstract Book and Excursion Guide. 9th SKAM Workshop, Moravian Museum, Brno, Czech Republic, October 8-11, 2012, Lithic Raw Materials - Phenomena of the Stone Age, red. P. Neruda, Z. Nerudova, Brno, s. 15-16.

2012b From far or from near? Sources of Kraków-Częstochowa banded and chocolate silicite raw material used during the Stone Age in Biśnik Cave (Southern Poland), Anthropologie. International Journal of the Science of Man, t. 50 (4), s. 411-425.

Krajcarz M. T., Madeyska T.

2010 Application of the weathering parameters of bones to stratigraphical interpretation of the sediments from two caves (Deszczowa Cave and Nietoperzowa Cave, Kraków-Częstochowa Upland, Poland), Studia Quaternaria, t. 27, s. 43-54.

Krajcarz M. T., Sudoł M., Krajcarz M., Cyrek K.

2012 Stanowisko późnoczwartorzędowych osadów jaskiniowych - Schronisko nad Jaskinią Zegar w Skałach Zegarowych (Wyżyna Częstochowska), Przegląd Geologiczny, t. 60 (10), s. 546-553.

Krajcarz M. T., Bosák P., Šlechta S., Pruner P., Komar M., Dresler J., Madeyska T.

2014 Sediments of Biśnik Cave (Poland): Lithology and stratigraphy of the Middle Palaeolithic site, Quaternary International, t. 326-337, s. 6-19, (DOI: http://dx.doi.org/10.1016/j.quaint.2013.10.017).

Machnik J.

1978 Wczesny okres epoki brazu, [w:] Prahistoria ziem polskich, t. 3: Wczesna epoka brązu, red. A. Gardawski, J. Kowalczyk, Wrocław, s. 9-136.

Mirosław-Grabowska J., Cyrek K.

2009 Archaeology and stratigraphy of the Jasna Strzegowska Cave, [w:] Karst of the Czestochowa Upland and of the Eastern Sudetes: palaeoenvironments and protection, red. K. Stefaniak, A. Tyc, P. Socha, Studies of the Faculty of Earth Sciences, University of Silesia, nr 56, Sosnowiec-Wrocław, s. 273-282.

Pelisiak A.

1993-1994 Jaskinia Biśnik (gmina Wolbrom, województwo katowickie) - badania z 1991 roku, Acta Archaeologica Carpatica, t. 32, s. 125-150. 
2003-2004 Ze studiów nad wykorzystywaniem surowców krzemiennych ze środkowej części Wyżyny Krakowsko-Częstochowskiej w późnym neolicie w strefie karpackiej. Neolityczne pracownie w Strzegowej (Strzegowa, stan. 42), Acta Archaeologica Carpatica, t. 38, s. 28-70.

2006 The exploitation and distribution of flints from the central part of Polish Jura in the Late Neolithic times, Analecta Archaeologica Ressoviensia, t. 1, s. 73-86.

Pelisiak A., Muzolf B.

1992 Jaskinia Biśnik, gm. Wolbrom, woj. Katowice. Badania 1991 rok, maszynopis w Instytucie Archeologii UMK, Łódź.

Sudoł M., Krajcarz M.T., Krajcarz M.

2013 Jaskinia Perspektywiczna - nowe stanowisko paleolityczne w Dolinie Udorki (Wyżyna Częstochowska), [w:] Materiały 47. Sympozjum Speleologicznego Olsztyn 17-20.10.2013, Olsztyn 2013, s. 75-76.

\section{EARLY BRONZE AGE SETTLEMENT EVIDENCE AT THE ROCKSHELTER IN UDÓRZ II (UDÓRZ, ŻARNOWIEC COMMUNE, ŚLĄSKIE VOIVODESHIP)}

\section{Summary}

The Rockshelter in Udórz II (Udórz, Żarnowiec Commune, Śląskie Voivodeship) lies at the northern end of the Udorka valley (fig. 1) in the Ryczów Upland (central portion of the Kraków-Częstochowa Upland). In 2012 an interdisciplinary programme of trial trenching was carried out at the shelter site (fig. 2) as one of the stages of a project designed to record evidence of prehistoric occupation in the Udorka valley and to examine its palaeoenvironmental context.

Sedimentary fill of this site comprise four strata of different lithology (fig. 3). The lowermost layer 4 is a sediment which was created by frost weathering in cold climatic conditions during the Pleistocene. Layer 3 consists of a light brown silty sand with a high content of sharp-edged debris, deposited during the Last Glacial Maximum. Layer 2 can be related to the Late Pleistocene and most of the Holocene. It is composed of grey-brown silty sand with a high content of sharp-edged limestone debris. In contrast, layer 1 is a dark grey-brown silty sand with small amounts of rounded limestone debris, which was formed in the warm climatic conditions of the Late Holocene.

Flintwork and potsherds were recorded at the interface of layers 1 and 2, and in the roof of layer 2. Analysis of distribution patterns reveals that these finds were concentrated around a hearth, traces of which were recorded at the south-west part of the trial trench (fig. 4). The small flintwork assemblage is not very distinctive and shows evidence of having been burnt (fig. 6: 1-3). Most of it forms a similar scatter to the pottery. 
The ceramic sherds represent the remains of at least three vessels, probably including a bowl; decoration in the form of cord impressions was noted on this pottery (fig. 5: 4-12). Based on typological, chronological and comparative studies this assemblage was attributed to the early period of development of the Mierzanowice culture, dated to 2200-2050 BC.

The fragmentary remains of a camp recorded at the Rockshelter in Udórz II suggest that as well as larger caves, late Neolithic and early Bronze Age communities also readily adapted smaller ones for use as short-term occupation sites, avoiding those where no daylight penetrated. This model of temporary or seasonal camps is consistent with current archaeological findings. Analysis of early Bronze Age materials from Małopolska (Little Poland) indicates that late Neolithic and early Bronze Age communities did not inhabit the Kraków-Częstochowa Upland on a permanent basis, only making forays into this area in search of flint and probably also rare plants and fruit.

Adres do korespondencji:

Magdalena Sudol, Kamil Adamczak

Instytut Archeologii

Uniwersytet Mikołaja Kopernika w Toruniu

ul. Szosa Bydgoska 44/48, 87-100 Toruń

sudol@umk.pl,adamczak@umk.pl

Maciej T. Krajcarz, Magdalena Krajcarz

Instytut Nauk Geologicznych

Polska Akademia Nauk

ul. Twarda 51/55, 00-818 Warszawa

mkrajcarz@twarda.pan.pl,magdakraj@twarda.pan.pl 